\title{
MANAGEMENT DEVELOPMENT OF DISTRICT IN THE ADMINISTRATION OF LOCAL GOVERNMENT IN EAST FLORES REGENCY, EAST NUSA TENGGARA PROVINCE
}

\author{
Fernandes SIMANGUNSONG, Simon Petrus LAMAWATO, Imelda HUTASOIT
}

Institute of Public Administration, Sumedang, Indonesia

\begin{abstract}
This study focused on exploring and analyzing management planning in the administration of local government, management of public services, and governmental leadership, while determining and analyzing the problems faced in the district management, as well as the possible development model for district management. This study used the constructivist approach (discovery and assimilation), and it involved 10 respondents. The results showed that in the district management in East Flores regency, the management of planning had not been implemented optimally; the management of public services had not been implemented optimally, effectively and efficiently; and the governmental leadership had been properly implemented in terms of service, but it had not been optimally implemented in terms of administrative management duties. The management development in the aspect of management of planning was expected to be carried out through these stages: setting goals, developing commitment to goals, developing effective action plan, following the steps of achieving the goals, and maintaining flexibility of planning.
\end{abstract}

Key Words: development of planning management, public service management, governmental leadership, administration of local government.

\section{Introduction}

The shift of the administrative paradigm from centralization to decentralization in essential had promoted change in the administration of government, development and public service in the course of good governance. In the globalization era, the public demand to government was for the government to implement the functions of the state properly (Curristine et al. 2007). This demand was normal and should be responded by the government by implementing significant and directed changes. In addition, the changes that were implemented by the government through planning, designing and realignment of organization and its management were positive in order to follow the progress of service paradigm into something that was currently highly expected by the public. Good governance could be achieved by administrating effective and efficient local government, implementing an evenly distributed regional development, and delivering quick, inexpensive, simple and high quality public services (Huther and Shah 2005, Adisasmita 2011, Nasution 2016).

Nowadays, the main problem faced by the government was the poor management, but not on what the government does, but on how the government did. The government failure in achieving public welfare was in its management (Winston 2006, Hepburn 2010, Keech and Munger 2015). It meant that the management factor plays a significant role in achieving the purpose of the state pursued by government in the aspect of social life. The fact was that people often complain about governance, one of which was the poor behaviors of the public apparatus for giving unsatisfactory services, such as the unfriendly attitude and throwing responsibility on each other. This condition had brought on the sarcasms about the poor behaviors of the public apparatus, such as: "if you could slow it down, why would you speed it up?", "if you could make it difficult, why would you make it easy?", and "if you could make it 
expensive, why would you make it cheap?" (Siswadi 2012).

Through the spirit of reform that came along with decentralization, it was necessary to execute the management alignment of the government in comprehensive, basic and conceptual manners, and to rebuild governmental management to be more responsive towards public demands and aspirations as well as external changes. This was in line with the government's spirit in the current President Joko Widodo administration, which was expressed in Nawa Cita. One of the agendas in Nawa Cita was to build clean, effective, democratic and reliable governance (Hafidz 2017, Hernayanto and Dewi 2017). Besides, the shift of paradigm in the administration of the government to be more system-oriented had made the role of management significant for a cooperation system. Thus, in the administration of the local government, management played a role to deal with local issues through collaboration between the classical approach (which focuses on productivity, technology, work design and methods, and the blue print of local governmental management), and the social approach (which emphasizes the attainment of efficiency and harmony in the workplace environment).

Management, in practice, was inseparable from policy. The management of local government, as demanded by the change in laws, should also transform along with the demand of globalization (Passaris 2006, Raharjo 2011). Management of local government, in the perspective of decentralization, aimed to accelerate the decision-making process to be more efficient, it increased the responsiveness to public needs, it accelerated the quality improvement of public services, it reduced the political intervention, it encouraged innovations, and it increased the personnel diligence and motivation (Pitono 2014). Many local governmental organizations in Indonesia had been mixing up the main duties and functions implemented by the organizational elements. There were staff functions and auxiliary functions that carry out operational activities of citizen administrative services or licensing services, or other activities directly related to the public. On the other hand, the line function that was supposed to play an important role in the operational activities was often paid less attention, both in terms of given authority and facilities.

The district (Kecamatan), as an organizational unit in the local government, had a strategic position as being in the front line to directly deliver services to the public with different backgrounds, needs and ever-changing demands (Zuhriyati and Rahmawati 2014). The district was the eye of the government to see, face and deal with the problems in the community. It meant that the district serves the service mission entrusted for the line function, such as to directly perform operational activities (to do, to act) of public services (Wasistiono et al. 2002). District organization was viewed as representative of the state and of the agency of local government that was always needed by the members of the community in the region. The roles of the district and the district head (Camat) as guardian, public protector and public servant should always be present in the function of the district.

This condition encouraged us as researchers to carry out a study focused on three main points: 1) the management of district in East Flores Regency in terms of management of planning, management of public services and governmental leadership; 2) the problems that were faced in dealing with the management of district in terms of management of planning, management of public services and governmental leadership in East Flores Regency, East Nusa Tenggara Province; and 3) the management development of district in terms of management of planning, management of public services and governmental leadership in East Flores Regency, East Nusa Tenggara Province. This study was expected to discover a new development concept and model to be applied in the local government that could cover not only Indonesia, but also foreign countries. 


\section{Methodology}

This study investigated the management development of local governmental administration at East Flores Regency East Nusa Tenggara province Indonesia. This study was proposed and designed to review and evaluate the local governmental administration to suggest several strategies of development for the succession and stability of the local government world-wide, especially in East Flores Regency, East Nusa Tenggara province, Indonesia. As a review, this study was based on the constructivist approach. The constructivist approach was a form of evaluation strategy based on basic assumptions that undergirded the constructivist paradigm. It had at least two phases on its application. The first phase was the discovery (represented the evaluator/researcher's efforts to describe what was going on the researched object). The second phase was the assimilation (represented by the evaluator/researcher's efforts to incorporate and to suggest new discoveries into the existing concept) (lofciu et al. 2012, Sutton and Austin 2015).

To this evaluative research, the researcher of this study firstly highlighted and reviewed the condition of the management at the local governmental administration in East Flores Regency, East Nusa Tenggara province (the discovery phase), and he suggested a new model as development on management at the local governmental administration in East Flores Regency, East Nusa Tenggara province (the assimilation phase). Thereby, to execute these processes, this study had employed several respondents whom were categorized into several titles:

1. Regent of East Flores

2. Chairman of Regional House of Representatives of East Flores Regency.

3. Assistant Regional Secretary for Government and Public Welfare of East Flores Regency.

4. Head of Regional Development Planning and Research and Development Agency of East Flores Regency.

5. Head of General Governmental Affairs Division of Regional Secretariat of East Flores Regency.

6. 5 representatives of district heads:

a. Head of Larantuka district - an urban district which had 18 sub-districts and 2 villages.

b. Head of Tanjung Bunga district - a district located at the eastern end of Flores island which had the largest area $\left(257.57 \mathrm{~km}^{2}\right.$ or $14.21 \%$ of total area size of East Flores Regency), with 16 villages, and a general topography of waving landscape and hills with a slope of $0-80^{\circ}$ from the sea level, thus having a relatively far and difficult access to several villages.

c. Head of East Adonara district - a district with the highest number of villages/ sub-districts (19 villages and 2 sub-districts), for which the access to the capital of the regency must be done by sea transportation.

d. Head of West Adonara district - a district with 18 villages, for which the access to services in several villages was relatively far and difficult in the west monsoon season and the access to the capital of the regency must be done by sea transportation.

e. Head of West Solor district - a district located in Solor island, with a topography of hills, thus having difficult access to several villages in the west monsoon season, and the access to the capital of the regency must be by sea transportation.

The conceptual operationalization as conceptual framework with the theme of local governmental strategies in improving the information technology-based integrated services and the subtheme of the five strategies concept for reinventing the government, as well as their definition, can be seen in the table of conceptual operationalization below (Table 1). 


\section{Conceptual Operationalization}

Table 1

\begin{tabular}{|c|c|c|}
\hline Concept & Aspect & Indicators \\
\hline \multirow{3}{*}{$\begin{array}{l}\text { Management of } \\
\text { District }\end{array}$} & $\begin{array}{l}\text { 1.Management of } \\
\text { Planning }\end{array}$ & Management of Planning in the District \\
\hline & $\begin{array}{l}\text { 2. Management of Public } \\
\text { Services }\end{array}$ & $\begin{array}{l}\text { Management of Public Services in the } \\
\text { District }\end{array}$ \\
\hline & $\begin{array}{l}\text { 3. Governmental } \\
\text { Leadership }\end{array}$ & District Governmental Leadership \\
\hline \multirow{6}{*}{$\begin{array}{l}\text { Problems faced } \\
\text { in management }\end{array}$} & \multirow{2}{*}{$\begin{array}{l}\text { 1. Management of } \\
\text { Planning }\end{array}$} & Internal Factors \\
\hline & & External Factors \\
\hline & \multirow{2}{*}{$\begin{array}{l}\text { 2. Management of Public } \\
\text { Services }\end{array}$} & Internal Factors \\
\hline & & External Factors \\
\hline & \multirow{2}{*}{$\begin{array}{l}\text { 3. Governmental } \\
\text { Leadership }\end{array}$} & Internal Factors \\
\hline & & External Factors \\
\hline \multirow{12}{*}{$\begin{array}{l}\text { Management } \\
\text { Development of } \\
\text { District in the } \\
\text { Administration of } \\
\text { Local } \\
\text { Government } \\
\text { (Selected Topics } \\
\text { on the } \\
\text { Management of } \\
\text { Local } \\
\text { Government, } \\
\text { Wasistiono } \\
\text { 2003) }\end{array}$} & \multirow{5}{*}{$\begin{array}{l}\text { 1. Management of } \\
\text { Planning } \\
\text { (Williams 2001) }\end{array}$} & 1.1. Setting goals \\
\hline & & 1.2. Developing commitment to goals \\
\hline & & 1.3. Developing an effective action plan \\
\hline & & $\begin{array}{l}\text { 1.4. Following the stages of goal } \\
\text { achievement }\end{array}$ \\
\hline & & 1.5. Maintaining flexibility of planning \\
\hline & \multirow{3}{*}{$\begin{array}{l}\text { 2. Management of Public } \\
\text { Services (Ratminto and } \\
\text { Winarsih 2008) }\end{array}$} & $\begin{array}{l}\text { 2.1. Service system emphasizing on } \\
\text { public interests }\end{array}$ \\
\hline & & $\begin{array}{l}\text { 2.2. Service culture in the organization } \\
\text { of the service provider }\end{array}$ \\
\hline & & $\begin{array}{l}\text { 2.3. Human Resources oriented on } \\
\text { public interests }\end{array}$ \\
\hline & \multirow{4}{*}{$\begin{array}{l}\text { 3. Governmental } \\
\text { Leadership } \\
\text { (Wasistiono 2013) }\end{array}$} & 3.1. Leader \\
\hline & & 3.2. Situation and Condition \\
\hline & & 3.3. Subordinate \\
\hline & & 3.4. Organizational vision and missions \\
\hline
\end{tabular}

Source: Williams (2001), Wasistiono (2003), Ratminto et al. (2008), Simangunsong (2016)

\section{Results}

Since the enactment of Law No. 22 of 1999 on the Local Government (followed by the Law No. 32 of 2004 and the Law No. 23 of 2014), all sectorial technical duties were entrusted by the central government to the local government of the regency/city. This condition caused the district organization to lose its authority to manage public services as it was taken over by the sectorial administration of the regency/city government. The district only became an institution which gave a recommendation to people who wanted to process licensing and citizen administrative services. This eventually made the bureaucratic chain longer (Jabes 2005).

In addition, the amendment of the Law on Local Government had brought the effect that all 
budgets for sectorial development were now under the authority of the regency government and implemented by the regional technical agencies and offices. The district's authority to plan and to implement the development in the district region was revoked. This condition described that the district organization was currently like "a toothless tiger", whose presence was felt, but unable to do anything for the community (Kolopaking 2010). The dysfunction of the district was caused by the absence of the authority to independently plan and manage the implementation of governmental activities and services in their own region.

In relation with the change of the main function of the local government from promoter of development to public service provider, the district should be and it was reasonably functioning as center for public services (Pusat Pelayanan Masyarakat - PUSYANMAS, Wasistiono et al. 2009). Moreover, the district was actually a medium for the formulation of alternative programs/ activities of development and empowerment as its position was close to the community and the villages/sub-districts.

The Law No. 23 of 2014 had confirmed that the purpose for the formation of the district in the regency/city was to increase the coordination of the administration of the government, the implementation of public services and community development in villages/sub-districts. This regulation implied that the district had a strategic position and it played a functional role in the governmental, development and social administration and services. The district was expected to be a local agency that could deliver public services with clear and transparent procedures, costs and delivery time. Therefore, the development of a district institutional model should be directed to follow the development trend of organizational and public administration theories (Motta and Schmitt 2013). District institutional development included aspects as follow: first, organizational structure; second, personnel; third, work mechanism; and fourth, performance measurement (Wasistiono et al. 2010). To ensure the implementation of district head's duties, the regent/mayor needed to delegate some of the administrative authorities to the district head as mandated by the Law on Local Government. The delegation of the authority was not only to provide legalization to the district head, but also to increase the effectiveness and efficiency in providing public services and using public funds and facilities. The effectiveness and efficiency of public services required good governance and management (Kefela 2011), which began with public service-oriented planning and it was supported by visionary leadership.

The consequence of the delegation of authority was that there would be different workloads between the districts which in turn resulted in a typology of districts: type $A-$ a district with heavy workload, and type B - a district with a light workload. The difference of type from the workload had affected the allocation of resources, such as personnel, finance and facilities and infrastructures. The implementation of position, duties and authorities of the district head in Indonesia was varied between regions (Blomkamp et al. 2017). Some local authorities still position the district head in an unclear situation. Most local authorities did not show a positive political will in the delegation of some of the authorities from regent to district head, and that district institution became susceptible to dysfunction as there was no clear duty to be entrusted by the regent/mayor. The district head was demanded to play a role like in the past, as the person in charge of a particular jurisdiction, but without a clear authority and source of finance. In other words, there was an imbalance between the district head's responsibility and the district head's authority and financing. As the implementation of Law No. 23 of 2014 on Local Government and Government Regulation No. 18 of 2016 on Local Bureaucracies, the East Flores Regency Government had issued the Regional Regulation of East Flores Regency No. 11 of 2016 on the Formation and Structure of Local Bureaucracies of East Flores Regency and the Regulation of East Flores Regent No. 98 of 2016 on the Position, Organizational Structure, Duties and Functions, and the Work Procedures of the District. Despite the fact that there was a difference in characteristics between districts (area size, number of villages/sub-districts, distance to the capital of the regency and geographical difficulty), both legal products were, in 
fact, uniform in typology (type A), organizational structure, duties and functions, and work procedures of the district.

East Flores Regency was one of the regencies in the administrative region of East Nusa Tenggara Province. It was an island regency with an area of $5,983.37 \mathrm{~km}^{2}$, consisting of $1,812.85 \mathrm{~km}^{2}$ of land area and of $4,170.53 \mathrm{~km}^{2}$ of sea area. Administratively, East Flores Regency consists of 19 districts, 229 villages and 21 sub-districts, and it consists of 251,611 inhabitants. The civil servant of East Flores Regency consists of 361 people. The distribution of the districts, the villages/sub-districts, was presented in the table below (Table 2).

Table 2

Data of Area Size and the Distribution of Villages and Sub-districts in the Districts of the Administrative Region of East Flores Regency

\begin{tabular}{|c|c|c|c|c|c|c|}
\hline Island & District & $\begin{array}{l}\text { Distance } \\
\text { to the } \\
\text { Capital of } \\
\text { the } \\
\text { Regency } \\
\text { (in km) }\end{array}$ & Village & $\begin{array}{c}\text { Sub- } \\
\text { district }\end{array}$ & $\begin{array}{c}\text { Area } \\
\text { size } \\
\left(\mathbf{k m}^{2}\right)\end{array}$ & $\begin{array}{l}\text { Area size } \\
\text { (in \%) }\end{array}$ \\
\hline & 1. Wulanggitang & 60.15 & 11 & - & 225.85 & 12.46 \\
\hline & 2. Titehena & 50.18 & 14 & - & 154.84 & 8.54 \\
\hline & 3. Tanjung Bunga & 28.24 & 16 & - & 257.57 & 14.21 \\
\hline & 4. Ile Mandiri & 11.40 & 8 & - & 72.76 & 4.01 \\
\hline & 5. Larantuka & 3.37 & 2 & 18 & 48.91 & 2.70 \\
\hline & 6. Demon Pagong & 26.12 & 7 & - & 85.40 & 4.71 \\
\hline & 7. Ile Bura & 66.45 & 7 & - & 118.32 & 6.53 \\
\hline & 8. Lewolema & 12.74 & 7 & - & 92.84 & 5.12 \\
\hline \multicolumn{2}{|c|}{ East Flores Land } & & & 18 & $1,056.49$ & 58.28 \\
\hline & 9. West Solor & 61.41 & 14 & 1 & 128.20 & 7.08 \\
\hline & 10. East Solor & 72.24 & 17 & - & 66.56 & 3.68 \\
\hline & 11. South Solor & 35.43 & 7 & - & 31.58 & 1.74 \\
\hline \multicolumn{2}{|l|}{ Solor } & & & 1 & 226.34 & 12.50 \\
\hline & 12. West Adonara & 18.15 & 18 & - & 79.71 & 4.40 \\
\hline & 13. Wotan Ulumado & 18.14 & 12 & - & 86.31 & 4.76 \\
\hline & 14. East Adonara & 40.86 & 19 & 2 & 91.06 & 5.02 \\
\hline & 15. Ile Boleng & 55.14 & 21 & - & 49.30 & 2.72 \\
\hline & 16 Witihama & 64.82 & 16 & - & 79.43 & 4.38 \\
\hline & 17. Kelubagolit & 45.11 & 12 & - & 44.41 & 2.45 \\
\hline & 18. Central Adonara & 38.33 & 13 & - & 42.73 & 2.36 \\
\hline & 19. Adonara & 35.21 & 8 & - & 56.80 & 3.13 \\
\hline \multicolumn{2}{|c|}{ Adonara } & & 119 & 2 & 529.75 & 29.22 \\
\hline \multicolumn{2}{|c|}{ East Flores Regency } & & 229 & 21 & $1,812.85$ & 100 \\
\hline
\end{tabular}

Source: IDR JMD of East Flores Regency, 2017-2022 (processed by the Researchers)

The table above showed the geographical condition of East Flores Regency with the distribution of districts and villages/sub-districts in 3 (three) large islands (eastern Flores land, 
Adonara and Solor). Tanjung Bunga was the district with the largest area, such as $257.57 \mathrm{~km}^{2}$, while the districts with the highest number of villages were East Adonara (19 villages and 2 sub -districts) and lle Boleng (21 villages). It was also known from the table that most of the districts were located relatively far (low reachability) from the capital of the regency, resulting in difficult and costly transportation for the access to and from the capital of the regency.

With the topography described above, the presence of the district was highly required by the community. The district with good governance was considered as the agency of local government of East Flores Regency for the role of guardian, public protector and public servant. However, the reality was far from expectation. Districts in East Flores Regency could not do much for the community. The districts had not been delegated with authority to plan and to manage the administrative activities, the public empowerment and service appropriately. One of the management aspects that was frequently complained by the community was the public service management in the district. Public services delivered by the district were far from satisfying the public expectations for quick, inexpensive, simple and good services.

There had been many members of the community complaining of the management of the public services, such as in processing citizenship documents (identity card or KTP) with a long procedure from the bottom level $(R T / R W)$, village/sub-district and district, to the Population Affairs and Civil Registration Agency of East Flores Regency. This kind of process was time, cost and effort consuming for the community. The far location caused many members of the community to use the service of illegal intermediaries (Calo) to process any document, resulting in the increase of costs and, in many cases, time delivery. In addition, there were also other problems, such as the unfriendly attitude of the apparatus in delivering services, and the identity card printing that could take one to two weeks. To respond to the aforementioned problems in public services, the East Flores Regency Government actually had issued the Regulation of East Flores Regent No. 3 of 2008 on the Delegation of Some of the Authorities in Governmental Affairs from Regent to District Head. One of the delegated authorities was the implementation of citizen administrative service activities. Moreover, in 2016, the East Flores Regency Government had also issued the Regulation of East Flores Regent No. 64.1 of 2016 on the Implementation of District Integrated Administrative Service (Pelayanan Administrasi TeIDR adu Kecamatan - PATEN) in East Flores Regency. However, both legal products were still unable to be implemented at the practice level. This was because there were no regulation/ technical guidelines for the delegation of authority and the implementation of PATEN in East Flores Regency, and due to the lack of support, personnel and logistics for the district.

In 2017, the total expenditure in the Regional Budget of East Flores Regency was of $74,935,809.22$ USD, and the amount allocated for the 19 districts was of 3,584,971.16 USD (or $5 \%$ of the total allocated expenditure in the Regional Budget of 2017). Besides, the budget allocation for the district in the budget year of 2018 can be seen in the table below (Table 3 ).

From the table above, the total allocated expenditure in the Regional Budget of East Flores Regency in 2018 was 79,107,331.89 USD, with an Indirect Expenditure of 45,743,271.18 USD $(57.8 \%)$ and an Indirect Expenditure of 33,365,485.95 USD (42.2\%). Of the total expenditure, the total budget allocated for the 19 districts in East Flores Regency in 2018 decreased from the previous year, such as $2,737,890.36$ USD $(3.46 \%$ of the total expenditure in the Regional Budget) with an Indirect Expenditure of $2,056,750.51$ USD (4.50\% of the total Indirect Expenditure) and a Direct Expenditure of $681,256.81$ USD (2.04\% of the total Direct Expenditure). This budget allocation was relatively small and uniform without considering the workload according to area size, topography, and number of villages/sub-districts with a difficult topography. This had impact on the less optimal implementation of the duties and functions of the district. 
Budget Allocation for the Districts in East Flores Regency (Budget Year 2018)

\begin{tabular}{|c|c|c|c|c|c|c|c|}
\hline \multirow{2}{*}{ No } & \multirow{2}{*}{ District } & \multicolumn{2}{|c|}{ Indirect Expenditure } & \multicolumn{2}{|c|}{ Direct Expenditure } & \multicolumn{2}{|l|}{ Amount } \\
\hline & & IDR in USD & $\%$ & IDR in USD & $\%$ & IDR in USD & $\%$ \\
\hline 1 & Wulanggitang & $\begin{array}{c}107,444.00 \\
\text { USD }\end{array}$ & 0.23 & $\begin{array}{c}24,644.78 \\
\text { USD }\end{array}$ & 0.07 & $\begin{array}{c}131,951.64 \\
\text { USD }\end{array}$ & 0.17 \\
\hline 2 & Titehena & $\begin{array}{c}89,667.58 \\
\text { USD }\end{array}$ & 0.20 & $\begin{array}{c}20,323.73 \\
\text { USD }\end{array}$ & 0.06 & $\begin{array}{c}109,877.10 \\
\text { USD }\end{array}$ & 0.14 \\
\hline 3 & Ile Bura & $\begin{array}{c}52,641.21 \\
\text { USD }\end{array}$ & 0.11 & $\begin{array}{c}25,634.92 \\
\text { USD }\end{array}$ & 0.08 & $\begin{array}{c}78,227.68 \\
\text { USD }\end{array}$ & 0.10 \\
\hline 4 & Tanjung Bunga & $\begin{array}{c}68,765.62 \\
\text { USD }\end{array}$ & 0.15 & $\begin{array}{c}24,066.49 \\
\text { USD }\end{array}$ & 0.07 & $\begin{array}{c}92,772.71 \\
\text { USD }\end{array}$ & 0.12 \\
\hline 5 & Lewolema & $\begin{array}{c}68,629.70 \\
\text { USD }\end{array}$ & 0.15 & $\begin{array}{c}23,269.02 \\
\text { USD }\end{array}$ & 0.07 & $\begin{array}{c}91,793.30 \\
\text { USD } \\
\end{array}$ & 0.12 \\
\hline 6 & Larantuka & $\begin{array}{c}583,132.02 \\
\text { USD }\end{array}$ & 1.27 & $\begin{array}{c}210,370.75 \\
\text { USD }\end{array}$ & 0.63 & $\begin{array}{c}792,502.19 \\
\text { USD }\end{array}$ & 1.00 \\
\hline 7 & Ile Mandiri & $\begin{array}{c}68,841.00 \\
\text { USD }\end{array}$ & 0.15 & $\begin{array}{c}21,291.19 \\
\text { USD }\end{array}$ & 0.06 & $\begin{array}{c}90,015.83 \\
\text { USD }\end{array}$ & 0.11 \\
\hline 8 & Demon Pagong & $\begin{array}{c}58,378.40 \\
\text { USD }\end{array}$ & 0.13 & $\begin{array}{c}21,027.67 \\
\text { USD }\end{array}$ & 0.06 & $\begin{array}{c}79,305.91 \\
\text { USD }\end{array}$ & 0.10 \\
\hline 9 & West Solor & $\begin{array}{c}73,746.06 \\
\text { USD }\end{array}$ & 0.16 & $\begin{array}{c}31,389.89 \\
\text { USD }\end{array}$ & 0.09 & $\begin{array}{c}105,135.95 \\
\text { USD }\end{array}$ & 0.13 \\
\hline 10 & South Solor & $\begin{array}{c}60,910.52 \\
\text { USD }\end{array}$ & 0.13 & $\begin{array}{c}25,517.27 \\
\text { USD }\end{array}$ & 0.08 & $\begin{array}{c}86,437.23 \\
\text { USD }\end{array}$ & 0.11 \\
\hline 11 & East Solor & $\begin{array}{c}81,733.38 \\
\text { USD }\end{array}$ & 0.18 & $\begin{array}{c}21,438.08 \\
\text { USD }\end{array}$ & 0.06 & $\begin{array}{c}103,183.31 \\
\text { USD }\end{array}$ & 0.13 \\
\hline 12 & West Adonara & $\begin{array}{c}99,506.05 \\
\text { USD }\end{array}$ & 0.22 & $\begin{array}{c}20,794.38 \\
\text { USD }\end{array}$ & 0.06 & $\begin{array}{c}120,282.12 \\
\text { USD }\end{array}$ & 0.15 \\
\hline 13 & Wotan Ulumado & $\begin{array}{c}70,888.75 \\
\text { USD }\end{array}$ & 0.15 & $\begin{array}{c}20,225.87 \\
\text { USD }\end{array}$ & 0.06 & $\begin{array}{c}91,103.08 \\
\text { USD }\end{array}$ & 0.12 \\
\hline 14 & Central Adonara & $\begin{array}{c}87,907.34 \\
\text { USD }\end{array}$ & 0.19 & $\begin{array}{c}24,507.51 \\
\text { USD }\end{array}$ & 0.07 & $\begin{array}{c}112,400.38 \\
\text { USD }\end{array}$ & 0.14 \\
\hline 15 & East Adonara & $\begin{array}{c}150,321.94 \\
\text { USD }\end{array}$ & 0.33 & $\begin{array}{c}63,546.95 \\
\text { USD }\end{array}$ & 0.19 & $\begin{array}{c}213,850.15 \\
\text { USD }\end{array}$ & 0.27 \\
\hline 16 & Ile Boleng & $\begin{array}{c}102,703.90 \\
\text { USD }\end{array}$ & 0.22 & $\begin{array}{c}21,009.77 \\
\text { USD }\end{array}$ & 0.06 & $\begin{array}{c}123,693.31 \\
\text { USD }\end{array}$ & 0.16 \\
\hline 17 & Witihama & $\begin{array}{c}\text { 69,516.58 } \\
\text { USD }\end{array}$ & 0.15 & $\begin{array}{c}31,381.93 \\
\text { USD }\end{array}$ & 0.09 & $\begin{array}{c}100,888.39 \\
\text { USD }\end{array}$ & 0.13 \\
\hline 18 & Kelubagolit & $\begin{array}{c}94,441.10 \\
\text { USD }\end{array}$ & 0.21 & $\begin{array}{c}26,475.65 \\
\text { USD }\end{array}$ & 0.08 & $\begin{array}{c}120,899.55 \\
\text { USD }\end{array}$ & 0.15 \\
\hline 19 & Adonara & $\begin{array}{c}68,787.70 \\
\text { USD }\end{array}$ & 0.15 & $\begin{array}{c}24,266.34 \\
\text { USD }\end{array}$ & 0.07 & $\begin{array}{c}93,042.57 \\
\text { USD }\end{array}$ & 0.14 \\
\hline \multicolumn{2}{|c|}{ Amount } & $\begin{array}{c}2,055,974.45 \\
\text { USD }\end{array}$ & 4.50 & $\begin{array}{c}681,043.40 \\
\text { USD }\end{array}$ & 2.04 & $\begin{array}{c}2,737,344.56 \\
\text { USD } \\
\end{array}$ & 3.46 \\
\hline \multicolumn{2}{|c|}{$\begin{array}{l}\text { Total Regional } \\
\text { Budget }\end{array}$} & $\begin{array}{c}\mathbf{4 5 , 7 2 7 , 9 6 4 . 4 8} \\
\text { USD }\end{array}$ & 57.8 & $\begin{array}{c}33,355,034.22 \\
\text { USD }\end{array}$ & 42.2 & $\begin{array}{c}79,091,561.91 \\
\text { USD }\end{array}$ & 100 \\
\hline
\end{tabular}

Source: Regional Budget of East Flores Regency, Budget Year 2018 (processed by the Researchers)

The Indirect Expenditure for the district was used for salary and allowances for all the district personnel in several district regions. The amount of the allocated budget in Direct Expenditure as in the table above had influence on the implementation of the main duties and functions of 
the district. The districts in East Flores Regency received the number of funds that was sufficient only for the routine activities. This was not in line with the mandate of the Law No. 23 of 2014 , that as a local bureaucracy, the district must make a strategic plan to support the accomplishment of the goals of the regency/city as stated in the IDR JMD. Therefore, the district should be and it was reasonably granted with sufficient funds to enable it to make the planning for the administrative, service and spatial development activities in its region (Kolopaking 2010).

In terms of human resources, the placement of civil servants in the district seemed disordered and poorly implemented, as seen in the table below (Table 4).

From the table above, the number of Civil Servants (PNS) placed in each district was not distributed proportionally according to the area size and the workload of each district. For example, in Ile Mandiri, with an area of $72.76 \mathrm{~km}^{2}$ and 8 villages in its territory, the number of the district personnel was greater (21 civil servants) than in West Solor, with an area of 128 $\mathrm{km}^{2}$ and 14 villages and 1 sub-district in its territory, which only had 16 civil servants. In terms of educational level, the placement of civil servants had not been fully supportive for the district organization, which would bring an impact on the performance of the district organization. These problems could still be found in every annual report of the district.

Number of Civil Servants of Districts in East Flores Regency, by Education Level

Table 4

\begin{tabular}{|c|c|c|c|c|c|c|c|c|}
\hline \multirow[b]{2}{*}{ No } & \multirow[b]{2}{*}{ District } & \multicolumn{6}{|c|}{ Educational Level } & \multirow[b]{2}{*}{ Number } \\
\hline & & SD & $\begin{array}{c}\text { Junior } \\
\text { High } \\
\text { School }\end{array}$ & $\begin{array}{l}\text { Senior } \\
\text { High } \\
\text { School }\end{array}$ & Diploma & Bachelor & Master & \\
\hline 1 & Wulanggitang & 2 & 2 & 15 & 2 & 4 & - & 25 \\
\hline 2 & Titehena & 2 & 2 & $\overline{10}$ & 2 & 3 & - & 19 \\
\hline 3 & Ile Bura & - & 1 & 9 & 1 & 4 & - & 15 \\
\hline 4 & Tanjung Bunga & - & 1 & 11 & - & 4 & - & 16 \\
\hline 5 & Lewolema & 1 & 1 & 7 & - & 4 & 1 & 14 \\
\hline 6 & Larantuka & - & - & 14 & - & 4 & - & 18 \\
\hline 7 & Ile Mandiri & - & - & 15 & 1 & 5 & - & 21 \\
\hline 8 & Demon Pagong & 1 & $\overline{1}$ & 8 & 1 & 5 & 1 & 17 \\
\hline 9 & West Solor & - & - & 11 & 2 & 3 & - & 16 \\
\hline 10 & South Solor & - & - & 7 & 1 & 3 & - & $\overline{11}$ \\
\hline 11 & East Solor & - & 1 & 15 & 3 & 4 & 1 & 24 \\
\hline 12 & West Adonara & 4 & 9 & 8 & 4 & 1 & 1 & 27 \\
\hline 13 & Wotan Ulumado & - & 3 & 11 & - & 5 & - & 19 \\
\hline 14 & Central Adonara & - & 3 & 12 & 4 & 3 & - & 22 \\
\hline 15 & East Adonara & 1 & 2 & 19 & 1 & 5 & - & 28 \\
\hline 16 & Ile Boleng & - & 3 & 18 & - & 6 & - & 27 \\
\hline 17 & Witihama & - & 2 & 12 & - & 6 & - & 20 \\
\hline 18 & Kelubagolit & - & - & 18 & 3 & 5 & - & 26 \\
\hline 19 & Adonara & - & - & 8 & 1 & 6 & 1 & 16 \\
\hline \multicolumn{2}{|c|}{ TOTAL } & 11 & 31 & 228 & 26 & 80 & 5 & 381 \\
\hline
\end{tabular}

Source: Report of the Administration of East Flores Regency Government, 2017 (processed by the Researchers)

The internal problems of the district government were: limited or lacking number of personnel, poor personnel discipline, apparatus' lack of understanding on the job description as implemented in the program description that was supposed to facilitate the service duties in the 
district office, and limited knowledge in making the Standard Operating Procedure (SOP) as guidelines for delivering service in the district office (Erawan 1999, Makaduro 2014, Syarifudin 2014, Anggraeni 2016). Moreover, the supporting facilities for the operational activities of the office and public service were still inadequate.

From the explanation above, there were incompatibilities between the main duties, functions and responsibilities of the district and the amount of funds allocated and the number of human resources placed in each district. In other words, the district was required for the implementation of its duties and it was accountable for its performance without sufficient support of inputs such as regulation, facilities and infrastructures, budget and other resources. This described the district's weak position in the administration of the local government in East Flores Regency, resulting in the poor implementation of its functions as provider of public services (Nursalam 2010, Mahsyar 2011). In this regard, the organizational and management development of the district was considered as an important agenda in the administration of the local government, especially in East Flores Regency.

\section{Discussion}

The law No. 23 of 2014 on the Local Government and the Regional Regulation No. 17 of 2018 on District suggested that the regency/city formed the district to increase the coordination of the administration of the government and the implementation of public services and public empowerment. In addition to the general administrative affairs, the district head was also delegated by the regent/mayor to implement some of the administrative affairs under the authority of the regency/city. The law and the regulation above have become the main bases on the importance of management development of district in East Flores Regency, East Nusa Tenggara Province, to achieve optimal public services. Singh (2011) states in-line that a mutual linkage is needed to establish a mutual relationship between the community and the government to achieve the governmental projects.

The management development above could be implemented on management of planning, management of public services and governmental leadership. All three aspects were considered as significant in district governance, because the management of planning was an important aspect in order to achieve the purpose of district organization, and to achieve optimal public services, visionary governmental leadership was needed (Chumaidi 2012, Rusniati and Haq 2014).

The implementation and development of organizational management in public sectors for achieving optimal public services, in general, faces many problems, both internal and external. Therefore, the concept of effective and efficient management development was necessary. To explain the relationship between these aspects, see the figure of the theoretical framework below (Fig. 1).

Based on the results of the study on the management development of districts in the administration of local government in East Flores regency, it could be explained that:

1. Management of district in East Flores Regency is evidenced in terms of management of planning, management of public services and governmental leadership.

a. Management of planning in the district in East Flores Regency has not been optimal yet. The district, with its strategic position in delivering public services, was not properly employed by the local government by giving it clear functions and a role in planning the administration of the government, and the implementation of development and public services.

b. Management of public services in the district in East Flores Regency has not been optimal, effective and efficient yet. Services were still centered on the regency, and 


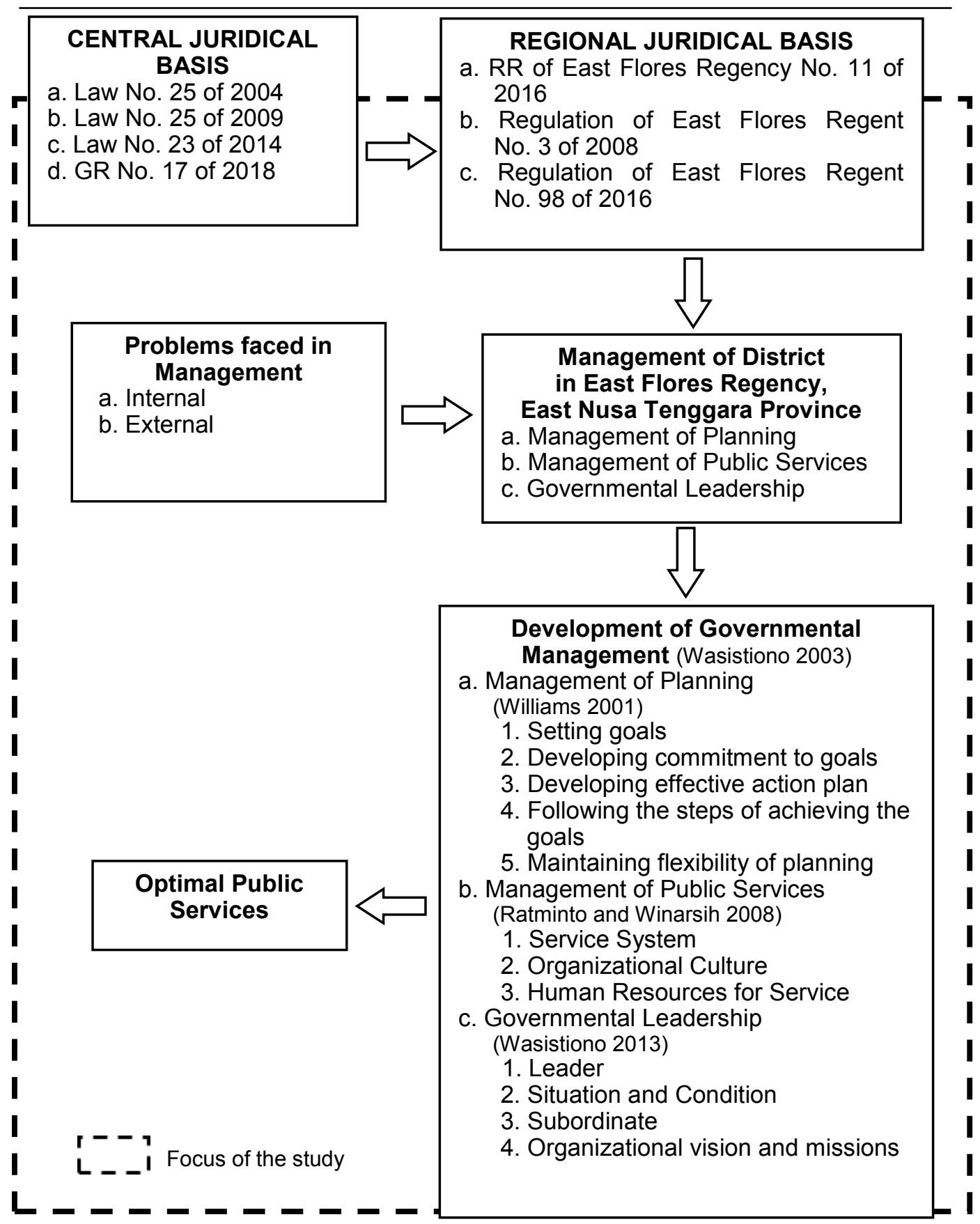

Fig. 1 - Theoretical Framework: Management Development of District in the Administration of Local Government in East Flores Regency, East Nusa Tenggara Province 
there was no proper Standard Operating Procedure for most of the services (making reference and recommendation letters) in the district. The position, functions and roles of the district were very limited in delivering optimal public services. This condition resulted in high costs and difficulty for the community to access public services, especially for the community who settles and lives in rural areas at East Flores Regency. The centered public administration should also take concern on how the community can access public services located in the centered public administration. By giving any accommodation (like transportation) would be sufficiently a good thing to help them.

c. Governmental leadership in the district in East Flores Regency, in terms of services, had been properly implemented. Despite of the limitations, the district head tended to use an open and non-formal leadership style in meeting public needs. However, for the implementation of administrative duties, governmental leadership in the district has not been optimal due to a lack of understanding on the governmental management resulting in using an incompatible leadership style.

2. Problems faced in dealing with the management of district in terms of management of planning, management of public services and governmental leadership in East Flores Regency, East Nusa Tenggara Province.

a. Problems faced in the management of planning in the district in East Flores Regency.

1) Among the internal problems, there were:

(a) Limited human resources

(b) Low level of human resources, resulting in a slow work method.

(c) Limited facilities and infrastructures.

(d) The budgets allocated to all districts were relatively the same and small in amount.

2) Among the external problems, there were:

(a) Lack of political will from the top leader to delegate some of the authorities from the regent to the district head, causing the district unable to make a development plan according to public needs and potentials.

(b) The presence of political interests (technocratic planning in clash with political planning).

(c) Lack of coordination between sectors/local bureaucracies, resulting in a lack of information on the development planning received by the districts.

(d) High sectorial egoism of local bureaucracies for not wanting to hand over their affairs/programs/activities to the districts.

(e) Low understanding of the public on the importance of planning, resulting in a low public participation in the district development planning forum (MUSRENBANG).

b. Problems faced in the management of public services in the district in East Flores Regency.

(1) Among the internal problems, there were:

(a) Limited number of personnel placed in the districts, with the level of human resources being incompatible with the requirement.

(b) Low mentality and work passion of the personnel.

(c) Limited budget allocated to the district.

(d) Limited supporting facilities and infrastructures for public service activities.

(e) Absence of clear SOP in regard to the service provided.

2) Among the external problems, there were:

(a) The delegation of some of authorities from the regent to the district has not been properly implemented.

(b) Difficult topography with damaged roads, resulting in difficult access from and to villages. 
(c) Limited information and communication network in the districts.

c. Problems faced in governmental leadership in the district in East Flores Regency.

(1) Among the internal problems, there were:

(a) Lack of administrative technical knowledge, resulting in the less optimal implementation of governmental management in the district.

(b) Absence of guardianship character in the leadership style.

(c) Incompatible health and mental condition of the district head with the given workload.

(d) Inadequate supporting personnel for the district head, both in quantity and quality.

(e) Limited budget and supporting facilities and infrastructures.

(2) Among the external problems, there were:

(a) Low public participation/support in all administrative activities.

(b) Difficult territorial characteristics and inadequate supporting infrastructures.

(c) Lack of commitment of the local government to support the districts; for example, authorities that had not been delegated, placement of district head that was not according to the regulation and requirement due to political interests, and perception of district as a dump for civil servants.

3. Management development of the district in terms of management of planning, management of public services and governmental leadership in East Flores Regency, East Nusa Tenggara Province.

a. The development of management of planning in the district in East Flores Regency was carried out by considering things as follows:

1) Setting goals.

Delegating authorities to the district in order to set its own specific, realistic reasonable, measurable, and timely goals, according to its own potentials.

2) Developing commitment to goals.

Requiring support from the regency government to develop commitment to district goals organizationally by placing personnel with capabilities as required and to distribute the resources (budget and facilities) as required. The support for the district personnel could take the form of encouragement/motivation, the implementation of reward and punishment, and the improvement of human resources.

3) Developing an effective action plan.

Carried out by making activity plans, including stages of goal achievement, requirement of resources, and scheduling of activities.

4) Following the stages of goal achievement.

Carried out by making the annual work plan (RENJA) as the elaboration of the strategic plan (RENSTRA) of the district which includes programs/ activities, performance indicators, the funding requirements, and the performance target. In addition, carrying out a working visit to the districts and meetings (work meetings and coordination meetings) are considered.

5) Maintaining flexibility of planning.

Carried out by making an alternative plan based on social dynamics, strengthening of regulation, district head's improvisation and courage in facing risks.

b. Development of management of public services in the district in East Flores Regency was carried out by placing the community as a top priority supported with:

1) Service System.

Carried out by bringing services closer to the community through delegating 
some of the authorities from the regent to the district head, integrating the development of information technology to the management of public services, implementing PATEN, making SOP for every service provided by the district and by implementing a voice mechanism, as well as strengthening the regulations.

2) Organizational/Service Culture.

Carried out by developing the culture of services oriented to public interests by applying principles such as: "to serve instead of being served", "make it easy instead of difficult", "be simple instead of complicated", "be inclusive instead of exclusive", "community are customers, not applicants", and by applying the Lamaholot culture.

3) Human Resources for the Service.

Carried by placing the appropriate human resources to the districts, and by developing human resources oriented to public services.

c. Development of governmental leadership in the district in East Flores Regency was carried out by considering variables as follows:

1) Leader.

The district head should be a leader of character with capability of managing, guiding, directing and motivating, who is open to input and who has a sense of service as well as initiative to make something new in achieving the purposes of the district.

2) Situation and Condition.

District head's leadership style that can understand the situation and condition of the district, and that can adapt to the dynamics of the environment.

3) Subordinate.

The district head should be able to understand the characteristics of the subordinates, to develop good communication and to apply a leadership style that could embrace and direct the subordinates to the goals set.

4) Organizational vision and missions.

The district head should have a personal vision in implementing a leadership style with orientation to the vision and missions of the district.

\section{Conclusions}

This study did not only give a theoretical development of district administration at local government level in East Flores Regency, but it also gave a considerable evaluation for the better improvement of public services and public administration centered in East Flores Regency. Therefore, from an overall explanation, the main findings related to the three topics arisen in this study were:

1) The problems that were faced in the management of planning were: a) internal problems that included the limited human resources, low quality of human resources, limited facilities and budget, and b) external problems that include the lack of political will, the influence of political interest, lack of coordination, high sectorial ego and low level of public understanding.

2) The problems faced in the management of public services were: a) internal problems that included the limited number of civil servants, absence of SOP, limited budget and facilities and infrastructures, and b) external problems that include the nondelegation of authority, difficult topography, and limited communication network.

3) The problems faced in governmental leadership were: a) internal problems that involved low administrative technical knowledge, incompatible leadership style, limited amount of budget, limited number of personnel, facilities and infrastructures, 
and b) external problems that include a low public participation, difficult conditions due to territorial characteristics, and the lack of commitment from the government.

This study was expected to give overcoming solutions for the improvement of public administration and public services at East Flores Regency. The researchers in this study believe that all data and results within this study have been empirically approved by the evidence in the field. Therefore, based on the research of this study, there are several recommendations as idea contribution for the East Flores Regency Government to formulate and to make policies related with the management development of the district in the administration of the Local Government in East Flores Regency.

1. Management of district in East Flores Regency in terms of management of planning, management of public services and governmental leadership.

a. Management of planning in the district.

In this case, the local government should realign the management of planning in the district by delegating authorities to the district to bridge between regency plans and public needs.

b. Management of public services in the district.

For this matter, the local government should optimize the strategic position, functions and roles of the district as agency of the regency by delegating some of the authorities from the regent to the district head on the public services along with a good SOP.

c. Governmental leadership in the district.

In this section, the local government should consider the requirement for hiring a civil servant on the district head position, and developing a leadership style of service.

2. Problems faced in the management of district in East Flores Regency.

a. Problems faced in the management of planning in the district:

1) Internal Problems:

(a) By increasing the number of district personnel.

(b) By improving the human resources of the district personnel.

(c) By improving the supporting facilities and infrastructures.

(d) By increasing the budget allocation for the districts.

2) External Problems:

(a) By building the political will of the top leader of East Flores Regency Government.

(b) By avoiding political interests.

(c) By improving coordination between sectors/local bureaucracies.

(d) By synchronizing the perception on the delegation of authorities from the regent to the district head.

(e) By increasing the public understanding on the importance of management of planning in the district.

b. Problems faced in the management of public services in the district:

1) Internal Problems:

(a) By increasing the number of civil servants in the district and by improving the human resources.

(b) By improving the work passion of the district personnel.

(c) By increasing the amount of the budget (direct expenditure) allocated to districts.

(d) By improving the supporting facilities and infrastructures for public service activities.

(e) By making and promoting SOP for every service provided.

2) External Problems:

(a) By building the political will of the regent to implement the delegation of authorities from the regent to the district head on public services. 
(b) By improving infrastructures (road) for access to and from villages.

(c) By improving the information and communication network in the districts. c. Problems faced in the governmental leadership of the district:

1) Internal Problems:

(a) By increasing the capacity of the district head in governmental management through regulation.

(b) By developing the district head's leadership style of guidance.

(c) By considering the health aspect of the civil servant whom was positioned as district head according to the conditions and workload of the district.

(d) By supporting the leadership of the district head by placing the adequate and competent human resources as district personnel.

(e) By supporting the leadership of the district head by strengthening the supporting facilities and budget.

2) External Problems:

(a) By making efforts to influence and motivate the community to support the leadership of the district head.

(b) By making efforts to improve infrastructures (road) to facilitate the district head in implementing the leadership function in the district.

(c) By building the commitment of the regency government to support the district organization by making the authorities of the district clear, by placing the district head according to regulation and requirement, by placing civil servants with good competences according to the requirements in the districts.

3) Management development of districts in terms of management of planning, management of public services and governmental leadership in East Flores Regency, East Nusa Tenggara Province.

a. Developing the management of planning in the district deals with five key points:

1) Setting goals.

The local government delegates the authorities to the district in order to set its own specific, realistic, reasonable, measurable, and timely goals according to its own potentials.

2) Developing commitment to goals.

The local government, through a support from the regency government, requires developing the commitment of the district to achieve the goals through strengthening the required resources and by motivating the district personnel to develop their competences.

3) Developing an effective action plan.

The local government establishes the program plans following the goal setting, along with the steps of achieving the goals, the requirements of resources and the time schedule.

4) Following the stages of achieving the goals.

The local government increases the quality of planning in the district (work plan and strategic plan), and the intensity of the working visits and the intensity of work and coordination meetings.

5) Maintaining flexibility of planning.

The local government strengthens and properly understands the regulation and the district head's capability in making alternative plans based on the social dynamics.

b. Developing the management of public services in the district deals with three key points:

1) Service System.

The local government makes the district as a center for public services with 
the principle of being close to the customer by delegating some of authorities from the regent to the district head, by implementing PATEN, making proper SOP, and applying a voice mechanism supported with adequate regulation.

2) Organizational/Service Culture.

The local government builds the organization culture of services oriented to public interests and local wisdom, and it applies the Lamaholot culture in the management of public services in the district.

3) Human Resources for the Service.

The local government develops the good management of the personnel by regulation.

c. Developing governmental leadership in the district deals with four key points:

1) Leader. Increasing the district head's capacity of leadership.

2) Situation and Condition.

Requiring the district head to understand the situation and condition of the district with a compatible leadership style.

3) Subordinate.

Increasing the district head's capability in understanding the characteristics of the personnel and the public, and developing the district head's communication ability to direct all elements of the district to achieve the goals set.

4) Organizational vision and missions.

Developing the district head's visionary leadership in implementing the function of the leadership with orientation to the organizational vision and missions of the district.

\section{References}

ANGGRAENI M. R. R. S. (2016), The role of Regional Agency of Business Management (BUMDES) on rural society's welfare: A study on Regional Agency of Business Management (BUMDES) at Gunung Kidul Yogyakarta, MODUS 28 (2), 155-167.

BLOMKAMP E., SHOLIKIN M. N., NURSYAMSI F., LEWIS J. M., TOUMBOUROU T. (2017), Understanding Policymaking in Indonesia: In Search of a Policy Cycle, The Policy Lab (University of Melbourne), The Indonesian Centre for Law and Policy Studies (PSHK), Retrieved from: www.pshk.or.id.

CHUMAIDI M. (2012), Optimizing the role of organization management in the management of high school, Jurnal Sains dan Teknologi 5 (1), 55-63.

CURRISTINE T., LONTI Z., JOUMARD I. (2007), Improving public sector efficiency: challenges and opportunities, OECD Journal on Budgeting 7 (1), 1-41.

ERAWAN I. K. P. (1999), Political reform and regional politics in Indonesia, Asian Survey 39 (4), 588-612.

HAFIDZ J. (2017), Nawacita and the law enforcement of civil state apparatus in constitutional law perspectives in Indonesia, Jurnal Pembaharuan Hukum 4 (2), 201-213.

HEPBURN C. (2010), Environmental policy, government, and the market, Oxford Review of Economic Policy 26 (2), 117-136.

HERNAYANTO Y., DEWI S. H. (2017), Good corporate governance for private multinational company to comply with global anti-bribery regulation (UK Bribery Act \& FCPA) and Indonesia company law, Advances in Social Science, Education and Humanities Research 131, 300-305.

HUTHER J., SHAH A. (2005), Applying a Simple Measure of Good Governance to the Debate on Fiscal Decentralization, The World Bank, Retrieved from: documents.worldbank.org. 
IOFCIU F., MIRON C., ANTOHE S. (2012), Constructivist approach of evaluation strategies in science education, Procedia - Social and Behavioral Sciences 31, 292-296. JABES J. (2005), The Role of Public Administration in Alleviating Poverty and Improving Governance, Asian Development Bank, Kuala Lumpur.

KEFELA G. T. (2011), Good governance enhance the efficiency and effectiveness public sending -Sub Saharan countries, African Journal of Business Management 5 (11), 39953999.

KEECH W. R., MUNGER M. C. (2015), The anatomy of government failure, Public Choice 164, 1-42. KOLOPAKING L. M. (2010), District for public welfare, PSP3-IPB, Bogor.

MAHSYAR A. (2011), The problem of public service in Indonesia in the perspective of public administration, Otoritas 1 (2), 81-90.

MAKADURO M. (2014), The application of discipline in improving district governmental apparatus working profession: A study on district governmental office at Mapangel Manado, Jurnal Politico 1 (4), 1-13.

MOTTA P. R., SCHMITT V. G. H. (2013), Administration for development: the idea and the renewal, Cadernos Ebape. $\mathrm{Br} 11$ (2), 197-206.

NURSALAM (2010), The implementation of policy on the improvement of local basic food production and local food tenacity at Nusa Tenggara Timur province, Jurnal Administrasi Publik 1 (1), 66-77.

PASSARIS C. E. (2006), The business of globalization and the globalization of business, Journal of Comparative International Management 9 (1), 3-18. NASUTION A. (2016), Government Decentralization in Indonesia, Asian Development Bank Institute, Retrieved from: www.adb.org.

PITONO A. (2014), Management of local government, IPDN Press, Jatinangor. RAHARJO A. (2011), Management of local government, Graha Ilmu, Yogyakarta.

RATMINTO, SEPTI W. A. (2008), Service management: development of conceptual model, application of citizen's charter and minimum service, Pustaka Pelajar, Yogyakarta. RUSNIATI, HAQ A. (2014), The strategic plannings in the perspective of organization, Jurnal Intekna 14 (2), 1-8.

SIMANGUNSONG F. (2016), Public administration research methodology, Alfabeta, Bandung.

SINGH P. (2011), Capacity development of local governance institutions in South Asia, Capacity Development of Local Governance Institutions in South Asia, PRIA Global Partnership, New Delhi.

SISWADI E. (2012), Future bureaucracy: towards effective and excellent governance, Mutiara Press, Bandung.

SUTTON J., AUSTIN Z. (2015), Qualitative research: data collection, analysis, and management, CJHP 68 (3), 226-231.

SYARIFUDIN A. (2014), The influence of human resource competence and process of internal audit towards the quality of local government finance report by intervening as system of internal government control, Jurnal Fokus Bisnis 14 (2), 26-44.

WASISTIONO S. (2003), Selected topics on management of local government (revised ed.), Fokus Media, Bandung.

WASISTIONO S. (2010), Model of district institutional development for optimization of public services, Seminar Proceeding at PKP2A I LAN RI. WASISTIONO S. (2013), Kapita Selekta Manajemen Pemerintahan, Alqaprint Jatinangor, Sumedang. WASISTIONO S., NURDIN I., FAHRUROZI M. (2009), Development of district organization from then to now, Fokusmedia, Bandung. WASISTIONO S., RIYANI O., YOUSA A., PITONO A. (2002), Institutional Realignment of District Government, Pusat Kajian Pemerintahan STPDN, Jatinangor. WILLIAMS C. (2001), Management: Book I, CRC Press, Boca Raton. 
Management Development of District in the Administration of Local Government in East Flores Regency, East Nusa Tenggara Province

WINSTON C. (2006), Government Failure versus Market Failure: Microeconomics Policy Research and Government Performace, AEI-Brookings Joint Center for Regulatory Studies, Washington D.C.

ZUHRIYATI E., RAHMAWATI D. E. (2014), Transformational leadership in the city of Yogyakarta during Herry Zudianto's era, Journal of Government and Politics 5 (2), 139-151.

Initial submission: 04.04.2019

Revised submission: 15.10 .2019

Final acceptance: 12.03 .2020

Correspondence: Institut Pemerintahan Dalam Negeri (IPDN), Jalan Ir. Soekarno KM 20, Desa Cibeusi, Jatinangor, Kabupaten Sumedang, Jawa Barat 45363, Indonesia.

Email: kisankiel@yahoo.co.id 
